Int. J. Dev. Biol. 59: 505-509 (2015)

doi: $10.1387 / \mathrm{ijdb} .150136 \mathrm{pr}$

\title{
CILP1 is dynamically expressed in the developing musculoskeletal system of the trout
}

\author{
CÉCILE RALLIERE, MAXENCE FRETAUD, VIOLETTE THERMES and PIERRE-YVES RESCAN* \\ INRA, UR1037 LPGP Fish Physiology and Genomics, Rennes, France
}

\begin{abstract}
An in situ screen for genes expressed in the skeletal muscle of eyed-stage trout embryos led to the identification of a transcript encoding a polypeptide related to CILP1, a secreted glycoprotein present in the extracellular matrix. In situ hybridisation in developing trout embryos revealed that CILP1 expression was initially detected in fast muscle progenitors of the early somite. Later, CILP1 expression was down-regulated medio-laterally in differentiating fast muscle cells, to become finally restricted to the undifferentiated muscle progenitors forming the dermomyotomelike epithelium at the surface of the embryonic myotome. At the completion of somitogenesis, CILP1 expression was concentrated in the myoseptal/tendon cells that develop between adjacent myotomes but was excluded from the skeletogenic cells of the vertebral axis to which the most medial myoseptal/tendon cells attach. Overall, our work shows that muscle cells and myoseptal/ tendon cells contribute dynamically and cooperatively to the production of CILP1 during ontogeny of the trout musculoskeletal system.
\end{abstract}

KEY WORDS: CILP1, somite, myotome, dermomyotome, myoseptal cell, teleost

In fish, the musculoskeletal system is a multicomponent system composed of W-shaped myomeres, myosepta and the axial skeleton. Myomeres arise from somites that are generated repeatedly from the presomitic mesoderm in an anterior to posterior progression. Two main muscle fibre types differentiate within somites: the superficial slow muscle fibres and the deep fast muscle fibres. Embryonic slow muscle fibres originate from adaxial cells, initially deep in the somite, that migrate radially to reach the lateral surface of the developing myotome, while embryonic fast muscle fibres derive from myogenic muscle cell precursors located in the posterior somitic compartment (for review see Bryson-Richardson and Currie, 2008). Cells of the anterior somitic compartment form a superficial dermomyotome-like epithelium surrounding the slow muscle fibres. This epithelium provides the myogenic precursor cells necessary for the growth of the embryonic myotome (Hollway et al., 2007; Stellabotte et al., 2007, Steinbacher et al., 2008). The fish myosepta that separate adjacent myomeres are medially inserted on the bony axial skeleton and are laterally connected to the collagenous dermis. Like tendons in amniotes, fish myosepta serve as transmitters of muscle contractility to bones. In the developing fish embryo, the myosepta are initially acellular and composed of matricial compounds such as fibronectin, laminin and collagens (Henry et al., 2005; Charvet et al., 2011; Bricard et al., 2014). After somitogenesis, myoseptal cells become appar- ent in the intersomitic space (Charvet et al., 2011; Bricard et al., 2014; Chen and Galloway., 2014; Subramanian and Schilling., 2014). These myoseptal cells are considered homologous to axial tenocytes in amniotes: they express scleraxis, tenomodulin and tendon associated collagens (Bricard et al., 2014; Chen and Galloway, 2014) and, like axial tenocytes in amniotes (Brent et al., 2003), they probably originate from a somite-derived syndetome compartment (Bricard et al., 2014; Chen and Galloway, 2014; Subramanian and Schilling, 2014). Experimental ablation of the myogenic factors myoD and myf5 in zebrafish results in the loss of scleraxis expression in the myosepta, showing that developing muscle regulates the specification of the myoseptal cell progenitors (Chen and Galloway, 2014).

Cartilage intermediate layer protein 1 (CILP1) is a large secreted glycoprotein present in the extracellular matrix. It was first isolated from extracts of human articular cartilage, and immunocytochemistry revealed that it localizes to the intermediate zone of articular cartilage in the territorial matrix (Lorenzo et al., 1998a). CILP1 is believed to play a role in cartilage scaffolding, and its dysfunction contributes to cartilage diseases (Seki et al., 2005). CILP1 has been shown to be synthesized as a precursor protein that is cleaved into

Abbreviations used in this paper: CILP1, cartilage intermediate layer protein 1.

\footnotetext{
*Address correspondence to: Pierre-Yves Rescan. INRA, UR1037 LPGP Fish Physiology and Genomics, F-35000 Rennes, France. Tel: 02-2348-5022; Fax: 02-2348-5020. E-mail: pierre-yves.rescan@rennes.inra.fr
}

Accepted: 18 June 2015.

ISSN: Online 1696-3547, Print 0214-6282 
distinct $\mathrm{N}$ - and $\mathrm{C}$ - terminal polypeptides at a furin endoprotease consensus site (Lorenzo et al., 1998b). The N-terminal half corresponds to CILP1 itself, while the C-terminal half may function as a nucleotide pyrophosphohydrolase (NTPPHase), as suggested by sequence homology, although its enzymatic activity has not yet been demonstrated (Johnson et al., 2003). Recently, expression of CILP1 has been reported in the heart and muscle of adult mice, suggesting additional roles for CILP1 in the extracellular matrix of

non-cartilaginous tissues (Bernardo et al., 2011).

Here, we report the identification of a trout gene orthologous to CILP1 and describe its developmental expression pattern. We show that CILP1 expression starts in the somite-derived embryonic fast muscle progenitors before becoming restricted to the dermomyotome-like epithelium that forms at the surface of the embryonic myotome. Finally, CILP1 expression concentrates in myoseptal cells invading the intersomitic space at the completion of somitogenesis.

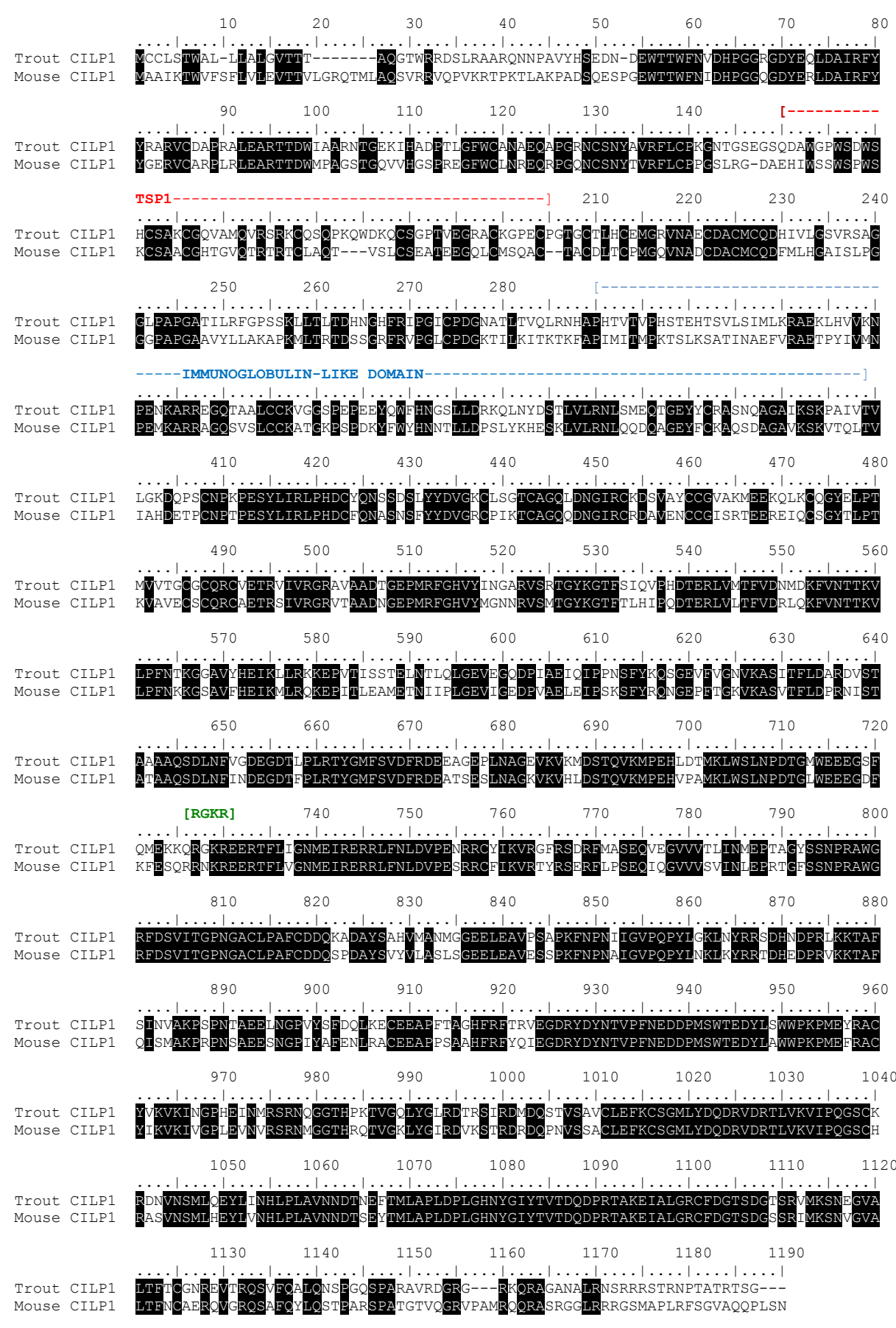

Fig. 1. Comparison of the predicted trout and murine CILP1 protein sequences. Shading indicates identity. The thrombospondin type 1 (TSP1) repeat domain (red segment), the immunoglobulin-like domain (blue segment) and the RGKR site for precursor cleavage catalysed by furin are indicated.

\section{Results and Discussion}

\section{Identification of a trout CILP1 cDNA}

Using a normalised library prepared from trout multi-tissue cDNAs, we performed a random in situhybridisation screen for genes expressed in the skeletal muscle of eyedstage trout embryos. Thus, we identified an EST cDNA clone which appeared to be expressed at the boundaries of the myotomes. Taking advantage of high-throughput sequencing of the trout genome (Berthelot et al., 2014), we then designed primers for the amplification of two overlapping cDNAs, which resulted in a full length CILP1 cDNA sequence (GenBank accession number KP898413), which exactly matched the complete coding sequence as deduced from the genomic contig. CILP1 full length cDNA encodes a protein of 1175 amino acids displaying $64 \%$ identity with mouse CILP1 (Fig.1). The identity of putative trout CILP1 protein was demonstrated using the MEGA 5.2 tools (Tamura et al., 2011) which unambiguously clustered it with the CILP1 protein from several species (Fig.2). A Kyte-Doolittle hydropathy plot displayed a putative signal peptide at the $\mathrm{N}$ terminus of CILP1 suggesting that CILP1 is a secreted polypeptide. PROSITE programs revealed a thrombospondin type 1 (TSP1) repeat domain at position (141-196) and an immunoglobulin-like domain at position (281-390). Also, a consensus sequence (RGKR), for precursor cleavage catalysed by furin, was identified at position 727-730 (Fig.1). Taken together, these observations show that trout CILP1exhibits the structural features of the mouse CILP1 protein (Lorenzo et al., 1998b).

\section{Expression pattern of CILP1 in the de- veloping trout embryo}

Whole-mount in situhybridisation, using an antisense CILP1 digoxigenin-labelled probe, showed that CILP1 transcript expression in trout embryo first occurred in somites approximately 9 days post fecundation and progressed caudally as somites formed in a 


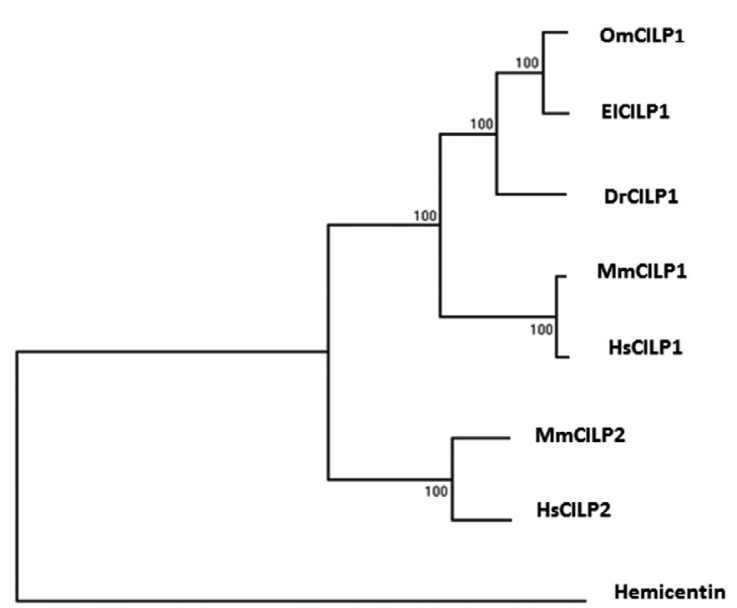

Fig. 2 (above left). Phylogenetic tree showing the relationship of the trout CILP1 protein to other vertebrate CILP proteins. The phylogenetic tree was constructed from a single multiple alignment of the complete protein sequences using the neighbor-joining method. Numbers at the tree nodes represent percentage of bootstrap values after 1000 replicates. Hemicentin was used as an outgroup. Accession numbers: Om (Oncorhynchus mykiss) CILP1: KP898413; El (Esox lucius) CILP1: (XP_010876921); Dr (Danio rerio) CILP1: (NP_001186291); Mm (Mus musculus) CILP1: (Q66K08); Hs (Homo sapiens) CILP1: (NP_003604); Mm (Mus musculus) CILP2: (NP_081094); Hs (Homo sapiens) CILP2: (NP_694953).

Fig. 3 (above right). Embryonic expression of CILP1 in the trout as shown by whole-mount in situ hybridisation. (A) Embryos at 9 dpf (approximately 25 somites) and (B) $10 \mathrm{dpf}$ (approximately 35 somites). CILP1 labelling is observed in somites (arrow). (C) Embryo at 17 dpf. CILP1 labelling is visualised at the anterior and posterior myotome borders. Scale bars, $400 \mu \mathrm{m}$.

rostral-to-caudal wave (Fig. 3A-C). CILP1 expression has also been reported in somites of early zebrafish embryos (Thisse and Thisse, 2004), but the cell types transcribing CILP1 were not specified. In trout, transverse sections clearly showed that the CILP1 transcript is initially present in fast muscle progenitors of the early somites, but is excluded from the adaxial slow muscle progenitors close to the notochord (Fig. 4A). Later in development, CILP1 expression disappeared medio-laterally in differentiating fast embryonic myoblasts (Fig. 4B), following a pattern similar to that of $\mathrm{N}$-cadherin (Rescan et al., 2012) and Seraf, an EGF-like repeat autocrine factor (Dumont et al., 2008). As the somites matured rostro-caudally, CILP1 expression became restricted to the dermomyotome-like

Fig. 4 (right). CILP1 is dynamically expressed during ontogeny of the trout musculoskeletal system. (A,B) Trout embryo at $10 \mathrm{dpf}$ (approximately 35 somites). (A) Transverse section through the posterior trunk. Labelling is visualised within the lateral fast muscle progenitors. (B) Transverse section through the middle trunk. CILP1 expression is down regulated medio-laterally in differentiating fast muscle cells. (C) Embryo at $13 \mathrm{dpf}$ (somitogenesis is virtually complete to the tip of the tail). Frontal section. Labelling is observed in the dermomyotome-like epithelium at the surface of the embryonic myotome. (D) Embryo at 16 dpf. Frontal section. Labelling is observed in myoseptal cells invading the intermyotomal space. (E) Embryo at $17 \mathrm{dpf}$. Frontal section. Labelling is confined to myoseptal cells present throughout the medio-lateral extent of the intermyotomal space, and residual labelling is observed in cells of the dermomyotome-like epithelium. (F) Embryo at $17 \mathrm{dpf}$. Dual-colour fluorescence in situ hybridization for Osf2/periostin (red fluorescence) and CILP1 (green fluorescence). Frontal section. CILP1 labelling is present in myoseptal cells and does not overlap Osf2/periostin labelling, which is restricted to skeletogenic cells around the notochord. nt: neural tube, fmp: fast muscle progenitors, ad: adaxial cells, n: notochord, der: dermomyotome, mc: myoseptal cells, myo: myotome, sc: skeletogenic cells. Scale bars, $50 \mu \mathrm{m}$.
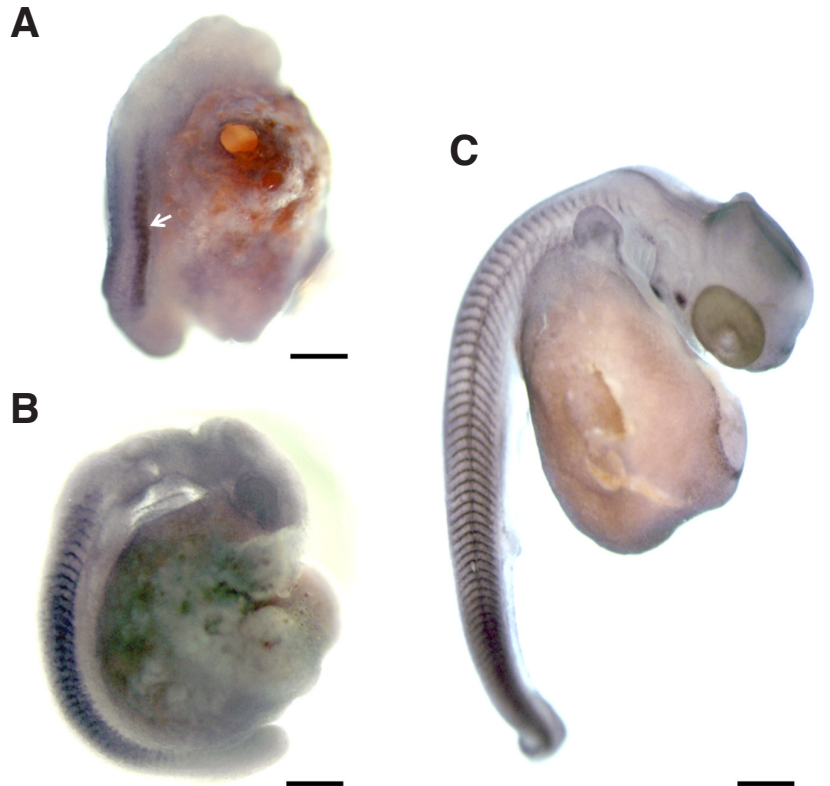
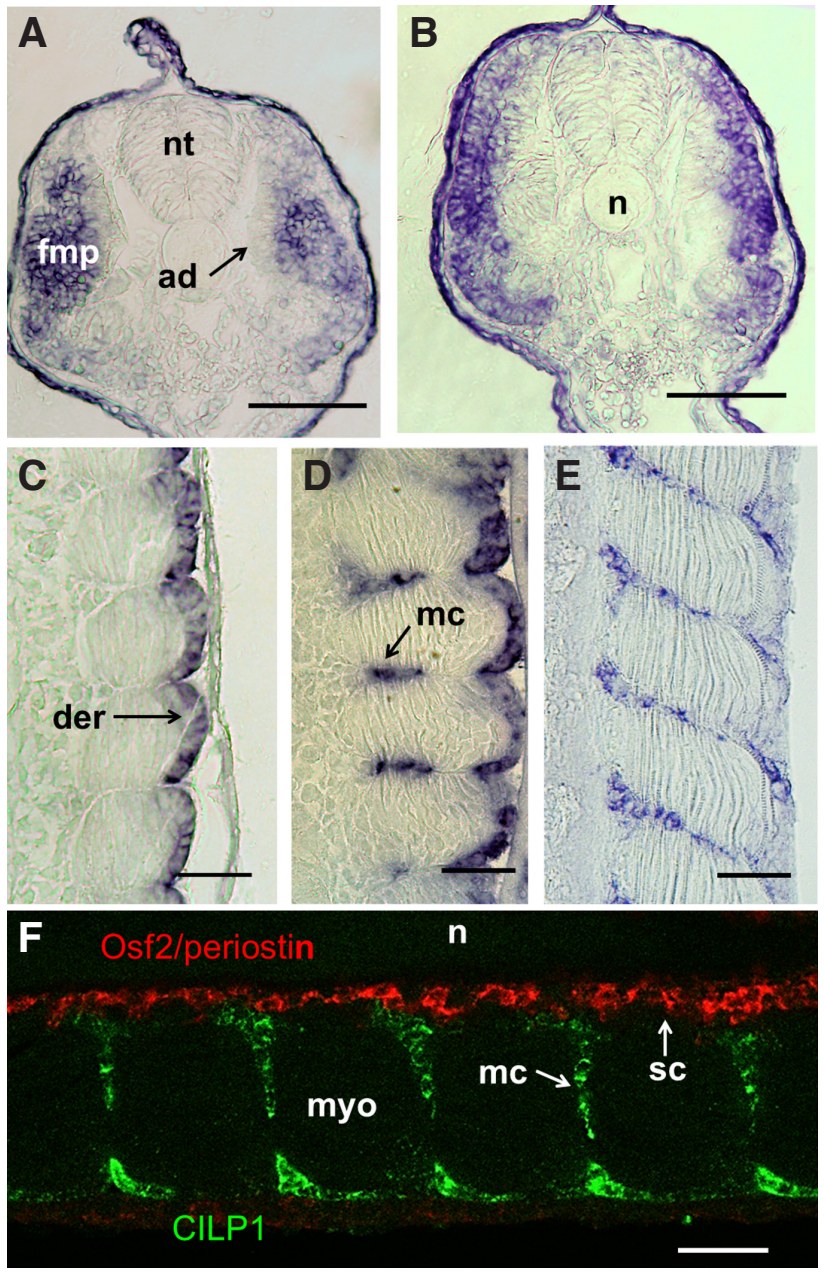
epithelium at the surface of the embryonic myotome (Fig. 4C). It has been shown that the dermomyotome-like epithelium provides muscle progenitors necessary for myotome growth, (Hollway et al., 2007; Stellabotte et al., 2007; Steinbacher et al., 2008) and, in line with their myogenic commitment, cells of the dermomyotome-like epithelium express the myogenic markers $\mathrm{Pax} 3$ and $\mathrm{Pax} 7$ as shown in zebrafish (Groves et al., 2005; Devoto et al., 2006; Hammond et al., 2007) and trout (Dumont et al., 2008). Our observation that the dermomyotome-like epithelium expresses CILP1 in addition to collagen I, V and XII (Bricard et al., 2014) further supports the view that this epithelium not only is myogenic, but also has a major role in the formation of the acellular connective tissue between the myotome and the epidermis. Whether this epithelium, which notably expresses dermo-1, a marker of dermis differentiation (Dumont et al., 2008), actually gives rise to cells of the dermis is still debated (Hollway et al., 2007; Stellabote etal., 2007). In eyed-stage embryos, whole mount in situ hybridisation showed that CILP1 labelling is found at the border of myotomes (Fig. 3C). Similar labelling has been reported in zebrafish embryos at late stages of development (Thisse and Thisse, 2004). To further identify cells expressing CILP1, frontal section through the trunk of eyed-stage trout embryos were cut. CILP1 expression was found to concentrate in myoseptal/tendon cells invading medio-laterally into the space separating adjacent myotomes (Fig.4 D and E). Myoseptal cells have been shown to express scleraxis, tenomodulin and tendon associated collagens and, as such, may be considered homologous to axial tenocytes in amniotes (Bricard et al., 2014; Chen and Galloway, 2014). Using combined fluorescence localization of CILP1 mRNA and osteoblastspecific factor 2 (Osf2)/periostin mRNA, we further observed that CILP1 labelling was excluded from the Osf2/periostin-expressing skeletogenic cells that surround the notochord and are abutted by the most medial CILP1 positive myoseptal cells (Fig. 4F). Skeletogenic cells surrounding the notochord have been shown to originate from the sclerotome compartment ventral to the myotome (Morin-Kensicki and Eisen, 1997). Although awaiting definitive evidence, it is likely that myoseptal/tendon cells originate from a sclerotome derivedcompartment similar to the syndetome of the amniotes (Bricard et al., 2014; Chen and Galloway, 2014; Subramanian and Schilling, 2014). Thus, although myoseptal and skeletogenic cells are likely to share a common sclerotomal origin, they rapidly differ not only by the expression of scleraxis and Osf2/periostin as previously reported (Bricard et al., 2014) but also by that of CILP1.

\section{Material and Methods}

\section{Fish maintenance}

All experiments reported in this study were performed on rainbow trout (Oncorhynchus mykiss) embryos, followed the recommendations of the "Comité National de Reflexion Ethique sur l'Experimentation Animale" of the Ministry of Higher Education and Research and were approved by the Local Animal Care and Use Committee (approval no 7I12). Eggs were collected at the experimental facilities of the INRA Drennec fish farm (Finistère, France). After artificial insemination, eggs were incubated at $10^{\circ} \mathrm{C}$ in recirculating dechlorinated water. Chemical water parameters were regularly monitored. Oxygen levels were always above $98 \%$ saturation. Samples were taken every day within the developmental period between the beginning of somitogenesis and the eyed-stage (7-17 days post fertilisation).

\section{Isolation of trout CILP CDNA}

CILP1 full length cDNA was obtained by the production of two overlapping PCR fragments amplified from newly hatched trout cDNA template, using primers that were designed from a genomic contig identified in the course of a high-throughput sequencing of the trout genome (Berthelot et al., 2014). Primer combinations for the production of the two overlapping cDNAs were as follows: sense primer (CAAGGTCAGAGGCAACAGCAGTG) and antisense primer (GACATGGGCAGAATATGCGTCAG) for the cDNA containing the start initiation codon; sense primer (GCCTGTCTGCCTGCCTTCTGCGA) and antisense primer (GGAGACCCTGATCTGTAGTGCTG) for the adjacent cDNA containing the stop codon.

\section{Whole-mount in situ hybridisation}

Digoxigenin-labelled antisense RNA probe for CILP1 was synthesised from PCR-amplified templates using the appropriate RNA polymerases. The embryos were dechorionated with fine forceps and fixed overnight at $4^{\circ} \mathrm{C}$ in paraformaldehyde in PBS. The specimens were dehydrated and stored in methanol at $-20^{\circ} \mathrm{C}$. Following rehydration in graded methanol/PBS baths, embryos were processed according to established procedures with minor modifications. Depending on the embryonic stage, different times, temperatures and concentrations were chosen for proteinase K treatment. A fluorescent in situ hybridization protocol using tyramide signal amplification was carried out for double in situ hybridization. Briefly, a CILP1 antisense riboprobe was labelled with digoxigenin-11UTP (Boehringer Mannheim) and an osteoblast-specific factor2/periostin antisense riboprobe (GenBank accession number KF640216) was labelled with fluorescein12-UTP (Boehringer Mannheim). Hybridisation was performed simultaneously with the two riboprobes. After washings and incubation with anti-digoxigenin-HRP, CILP1 fluorescent expression was revealed with TSA-plus FITC (Perkin Elmer LAS). Quenching of HRP was then performed in $50 \%$ formamide/2SSC/ Tween $0.1 \%$, for 30 minutes at $65^{\circ}$. After extensive washes in PBST, the embryos were incubated with anti-fluorescein-HRP and periostin fluorescent expression was revealed with TSA-plus Cyanine3 (Perkin Elmer LAS).

\section{Histological methods}

For histological examinations, embryos were embedded in $30 \%$ ovalbumin, $0.5 \%$ gelatine and $1 \%$ gluteraldehyde in PBS. Blocks were sectioned at $30 \mu \mathrm{m}$ on a Leica vibratome. The resulting sections were mounted in Mowiol.

\section{Fluorescent microscopy}

Embryos were mounted in 4\% agarose and examined using the VibMic combination system (Leica $\left.{ }^{\circledR}\right)$ that enables accessibility of deep structures of large whole-mount specimens by the combination of a vibratome (VT1200S) with a SP8 confocal microscope. Serial frontal sections were made along the dorso-ventral axis of the embryo. Then, block-face imaging was performed with a 25x/0.95 water immersion objective. Images were visualized and processed through ImageJ software to adjust contrast, brightness, and dynamic range.

\section{Acknowledgements}

The research leading to these results received funding from the European Community's Seventh Framework Programme (FP7/2007-2013) under grant agreement no. 222719 - LIFECYCLE. We thank Cecile Melin and Jean-Luc Thomas for obtaining and rearing the trout embryos, Florence Lefevre and Jean-Charles Gabillard for their help and discussions. This work has benefited from the facilities and expertise of the Tefor Fish Phenotyping Platform located at INRA-LPGP (ANR-II-INBS-0014).

\section{References}

BERNARDO, B.C., BELLUOCCIO, D., ROWLEY, L., LITTLE, C.B., HANSEN, U. and BATEMAN, J.F. (2011). Cartilage intermediate layer protein 2 (CILP-2) is expressed in articular and meniscal cartilage and down-regulated in experimental osteoarthritis. J Biol Chem 286: 37758-37767.

BERTHELOT, C., BRUNET, F., CHALOPIN, D., JUANCHICH, A., BERNARD, M., NOËL, B., BENTO, P., DA SILVA, C., LABADIE, K., ALBERTI, A., AURY, J.M., LOUIS, A., DEHAIS, P., BARDOU, P., MONTFORT, J., KLOPP, C., CABAU, C., GASPIN, C., THORGAARD, G.H., BOUSSAHA, M., QUILLET, E., GUYOMARD, R., GALIANA, D., BOBE, J., VOLFF, J.N., GENÊT, C., WINCKER, P., JAILLON, 
O., ROEST CROLLIUS H., and GUIGUEN, Y. (2014). The rainbow trout genome provides novel insights into evolution after whole-genome duplication in vertebrates. Nat Commun 5: 3657.

BRENT, A. E., SCHWEITZER, R., and TABIN C.J. (2003). A somitic compartment of tendon progenitors. Cell 113: 235-248.

BRICARD, Y., RALLIÈRE, C., LEBRET, V., LEFEVRE, F., and RESCAN, P.Y. (2014). Early fish myoseptal cells: insights from the trout and relationships with amniote axial tenocytes. PLoS One 9: e91876.

BRYSON-RICHARDSON, R. J. and CURRIE, P. D. (2008). The genetics of vertebrate myogenesis. Nat Rev Genet 9: 632-646.

ChARVET, B., MALBOUYRES, M., PAGNON-MINOT, A., RUGGIERO, F., and LE GUELLEC, D. (2011). Development of the zebrafish myoseptum with emphasis on the myotendinous junction. Cell Tissue Res 346: 439-449.

CHEN, J. W. and GALLOWAY, J. L. (2014). The development of zebrafish tendon and ligament progenitors. Development 141: 2035-2045.

DEVOTO, S. H., STOIBER, W., HAMMOND, C. L., STEINBACHER, P., HASLETT, J. R., BARRESI, M. J., PATTERSON, S. E., ADIARTE, E. G., and HUGHES, S. M. (2006). Generality of vertebrate developmental patterns: evidence for a dermomyotome in fish. Evol Dev 8: 101-110.

DUMONT, E., RALLIĖRE, C., and RESCAN, P. Y. (2008). Identification of novel genes including Dermo-1, a marker of dermal differentiation, expressed in trout somitic external cells. J Exp Biol 211: 1163-1168.

GROVES, J. A., HAMMOND, C. L., and HUGHES, S. M. (2005). Fgf8 drives myogenic progression of a novel lateral fast muscle fibre population in zebrafish. Development 132: 4211-4222.

HENRY, C. A., MCNULTY, I. M., DURST, W. A., MUNCHEL, S. E., and AMACHER, S. L. (2005). Interactions between muscle fibers and segment boundaries in zebrafish. Dev Biol 287: 346-360.

HAMMOND, C. L., HINITS, Y., OSBORN, D. P., MINCHIN, J. E., TETTAMANTI, G., and HUGHES, S. M. (2007) Signals and myogenic regulatory factors restrict pax3 and pax7 expression to dermomyotome-like tissue in zebrafish. Dev Bio/302:504-521.

HOLLWAY, G.E., BRYSON-RICHARDSON, R., BERGER, S., COLE, N.J., HALL, T. E., and CURRIE, P.D. (2007). Whole somite rotation generates muscle progenitor cell compartments in the developing embryo. Dev Cell 12: 207-219.

JOHNSON, K., FARLEY, D., HU, S. I., and TERKELTAUB, R. (2003). One of two chondrocyte-expressed isoforms of cartilage intermediate-layer protein functions as an insulin-like growth factor 1 antagonist. Arthritis Rheum 48: 1302-1314.

LORENZO, P., BAYLISS, M.T., and HEINEGÅRD, D. (1998a). Anovel cartilage protein (CILP) present in the mid-zone of human articular cartilage increases with age. $J$ Biol Chem 273: 23463-23468.

LORENZO, P., NEAME, P., SOMMARIN, Y., and HEINEGÅRD, D. (1998b). Cloning and deduced amino acid sequence of a novel cartilage protein (CILP) identifies a proform including a nucleotide pyrophosphohydrolase. J Biol Chem 273: 23469-23475.

MORIN-KENSICKI, E.M. and, EISEN, J.S. (1997). Sclerotome development and peripheral nervous system segmentation in embryonic zebrafish. Development 124: 159-167.

RESCAN, P. Y., RALLIERE, C., and LEBRET, V. (2012). N-cadherin and M-cadherin are sequentially expressed in myoblast populations contributing to the first and second waves of myogenesis in the trout (Oncorhynchus mykiss). J Exp Zool $B$ Mol Dev Evol 318: 71-77.

SEKI, S., KAWAGUCHI, Y., CHIBA, K., MIKAMI, Y., KIZAWA, H., OYA, T., MIO, F., MORI, M., MIYAMOTO, Y., MASUDA, I., TSUNODA, T., KAMATA, M., KUBO, T. TOYAMA, Y., KIMURA, T., NAKAMURA, Y., and IKEGAWA, S. (2005). A functional SNP in CILP, encoding cartilage intermediate layer protein, is associated with susceptibility to lumbar disc disease. Nat Genet 37: 607-612.

STEINBACHER, P., STADLMAYR, V., MARSCHALLINGER, J., SÄNGER, A. M., and STOIBER, W. (2008). Lateral fast muscle fibers originate from the posterior lip of the teleost dermomyotome. Dev Dyn 237: 3233-3239.

STELLABOTTE, F., DOBBS-MCAULIFFE, B., FERNANDEZ, D.A., FENG, X., and DEVOTO, S.H. (2007). Dynamic somite cell rearrangements lead to distinct waves of myotome growth. Development 134: 1253-1257.

SUBRAMANIAN, A. and SCHILLING, T. F. (2014). Thrombospondin-4 controls matrix assembly during development and repair of myotendinous junctions. Elife 3 : e02372.

TAMURA, K., PETERSON, D., PETERSON, N., STECHER, G., NEI, M., AND KUMAR, S. (2011). MEGA5: molecular evolutionary genetics analysis using maximum likelihood, evolutionary distance, and maximum parsimony methods. Mol. Biol. Evol 28: 2731-2739.

THISSE, B. and THISSE, C. (2004). Fast Release Clones: A High Throughput Expression Analysis. ZFIN Direct Data Submission (http://zfin.org). 
A Sox 5 gene is expressed in the myogenic lineage during trout embryonic development Pierre-Yves Rescan and Cecile Ralliere

Int. J. Dev. Biol. (2010) 54: 913-918

http://www.intjdevbiol.com/web/paper/092893pr

Dual embryonic origin of the hyobranchial apparatus in the Mexican axolotl (Ambystoma mexicanum)

Asya Davidian and Yegor Malashichev

Int. J. Dev. Biol. (2013) 57: 821-828

http://www.intjdevbiol.com/web/paper/130213ym

Expression of Sox family genes in early lamprey development

Benjamin R. Uy, Marcos Simoes-Costa, Tatjana Sauka-Spengler and Marianne E. Bronner

Int. J. Dev. Biol. (2012) 56: 377-383

http://www.intjdevbiol.com/web/paper/113416bu

A Sox 5 gene is expressed in the myogenic lineage during trout embryonic development Pierre-Yves Rescan and Cecile Ralliere

Int. J. Dev. Biol. (2010) 54: 913-918

http://www.intjdevbiol.com/web/paper/092893pr

Regulatory elements of Xenopus col2a1 drive cartilaginous gene expression in transgenic frogs

Ryan Kerney, Brian K. Hall and James Hanken

Int. J. Dev. Biol. (2010) 54: 141-150

http://www.intjdevbiol.com/web/paper/092848rk

S. macrurus myogenic regulatory factors (MRFs) induce mammalian skeletal muscle differentiation; evidence for functional conservation of MRFs

Hyun-Jung Kim, Robert Güth, Colleen B. Jonsson and Graciela A. Unguez

Int. J. Dev. Biol. (2009) 53: 993-1002

http://www.intjdevbiol.com/web/paper/082672hk

Regulation of the mouse alfaB-crystallin and MKBP/HspB2 promoter activities by shared and gene specific intergenic elements: the importance of context dependency Shivalingappa K. Swamynathan and Joram Piatigorsky

Int. J. Dev. Biol. (2007) 51: 689-700

http://www.intjdevbiol.com/web/paper/072302ss

5 yr ISI Impact Factor $(2013)=2.879$
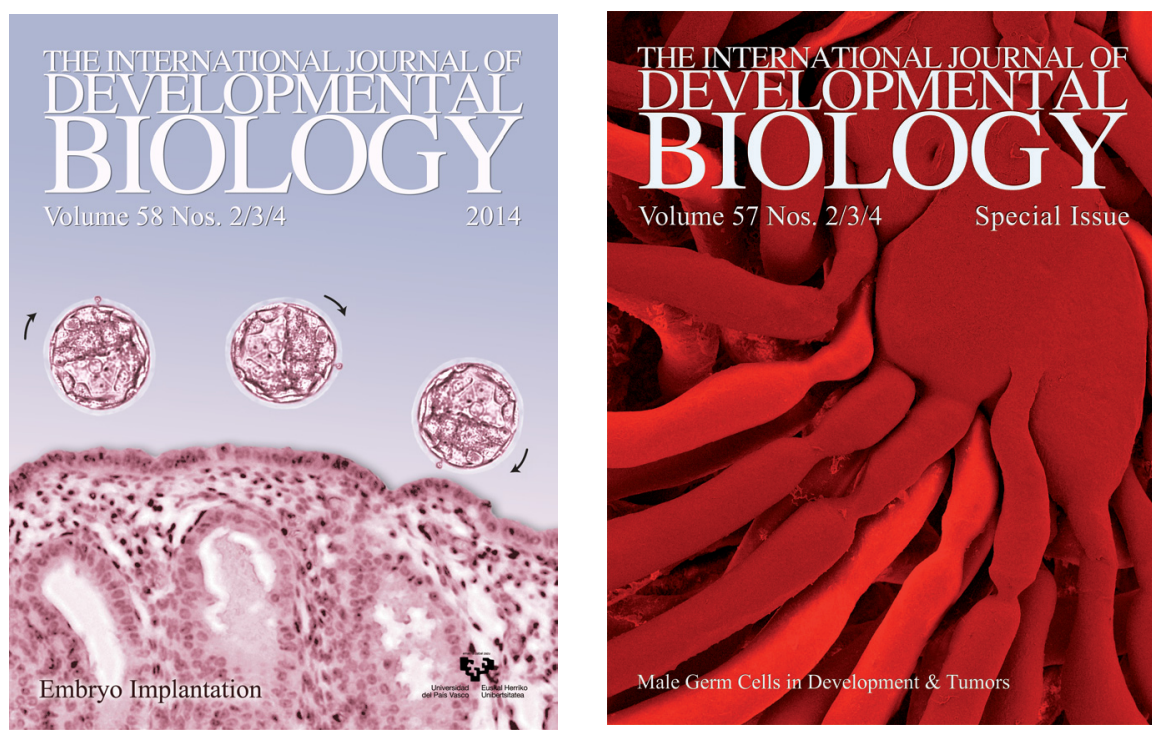

THEINTERNATIONAL JOURNAL OF DEVELOPVIENTAI

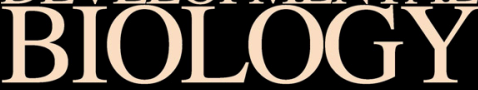
Volume 58 Nos. $6 / 7 / 8$ 2014

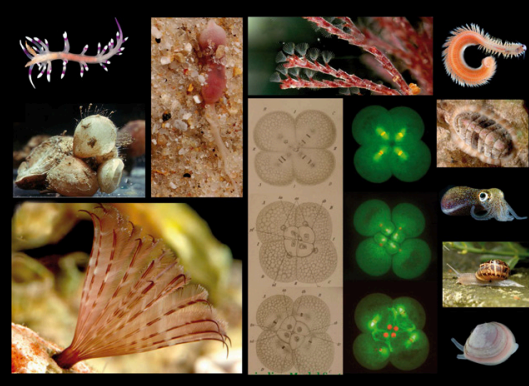

Spiralian Model Systems 4

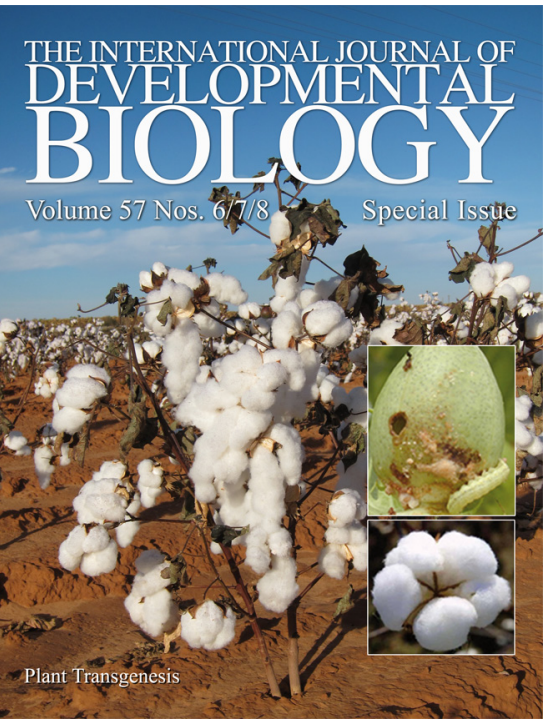

